\title{
GLYCOGEN IN NON-GERMINAL CELLS OF RAT TESTIS FOLLOWING GAMMA-IRRADIATION
}

\author{
G. S. GUPTA AND S. R. BAWA \\ Department of Biophysics, Panjab University, Chandigarh, India
}

(Received 21st January 1974)

Glycogen has been demonstrated in non-germinal cells of the testes in many species (Free, 1970). In the rat, however, the Sertoli cells and the interstitial cells are characterized by the absence of glycogen (Nicander, 1957; Leiderman \& Mancini, 1969). The germinal cells are the major sites for the deposition of glycogen and their content declines progressively from the immediate postnatal period to adult-hood (Leiderman \& Mancini, 1969). As atrophic testes resulting from irradiation consist largely of non-germinal cells (Ellis, 1970), it is assumed that the changes in the glycogen levels in such testes mirror the events associated with the interstitial and Sertoli cells.

Normal adult rats ( 150 to $200 \mathrm{~g}$ ) were allocated to fifteen groups, with three to five rats in each group. Anaesthetized rats, without shielding, were laid in a supine position on a dissecting board. The body area inferior to the penis was exposed to a single uniformally distributed dose of $\gamma$-rays at a distance of $65 \mathrm{~cm}$ from the source within a field of exposure of $25 \times 25 \mathrm{~cm}^{2}$ (Gupta \& Bawa, 1971). Immediately outside the field of exposure, $\gamma$-ray scattering was undetectable by phantom dosimetry. Sham-irradiated animals acted as controls. Feeding was stopped 6 to $8 \mathrm{hr}$ before the rats were killed by decapitation. Estimations were carried out, in duplicate, using 200 to $400 \mathrm{mg}$ pooled tissue from a group. The tissue was added directly to hot $30 \%$ potassium hydroxide, and the glycogen was extracted and analysed by the method of Seifter, Daton, Movic \& Muntwyler (1960). Post-irradiation values for glycogen, expressed in $\mu \mathrm{g} / \mathrm{g}$ testis and as a percentage of the control values, are shown in Text-fig. 1, and values, expressed as percentage of the control values per testis are given in Text-fig. 2. The effect of different doses of radiation on testis glycogen is shown in Text-fig. 3. The changes in the weight of testis following irradiation are recorded in Table 1.

The data shown in Text-fig. I(b) indicate that there is an initial increase in the glycogen/g testis by about Day 5 after irradiation. This is followed by a fall to about the normal range on Day 20, followed by a further increase by Day 30. Subsequently, the level of glycogen is reasonably maintained. When expressed in terms of glycogen/testis (Text-fig. 2), there is again an increase by Day 5 , followed by a fall and, thereafter, the glycogen level remains at or near the normal level. Text-figure 3(a) shows that glycogen accumulation/g testis 15 days after irradiation is a dose-response phenomenon and increases with increasing doses up to $6000 \mathrm{R}$. In terms of glycogen/testis, however, the level at different doses does not deviate from the normal range (Text-fig. $3 \mathrm{~b}$ ).

The mechanism responsible for the accumulation of glycogen in the testis 


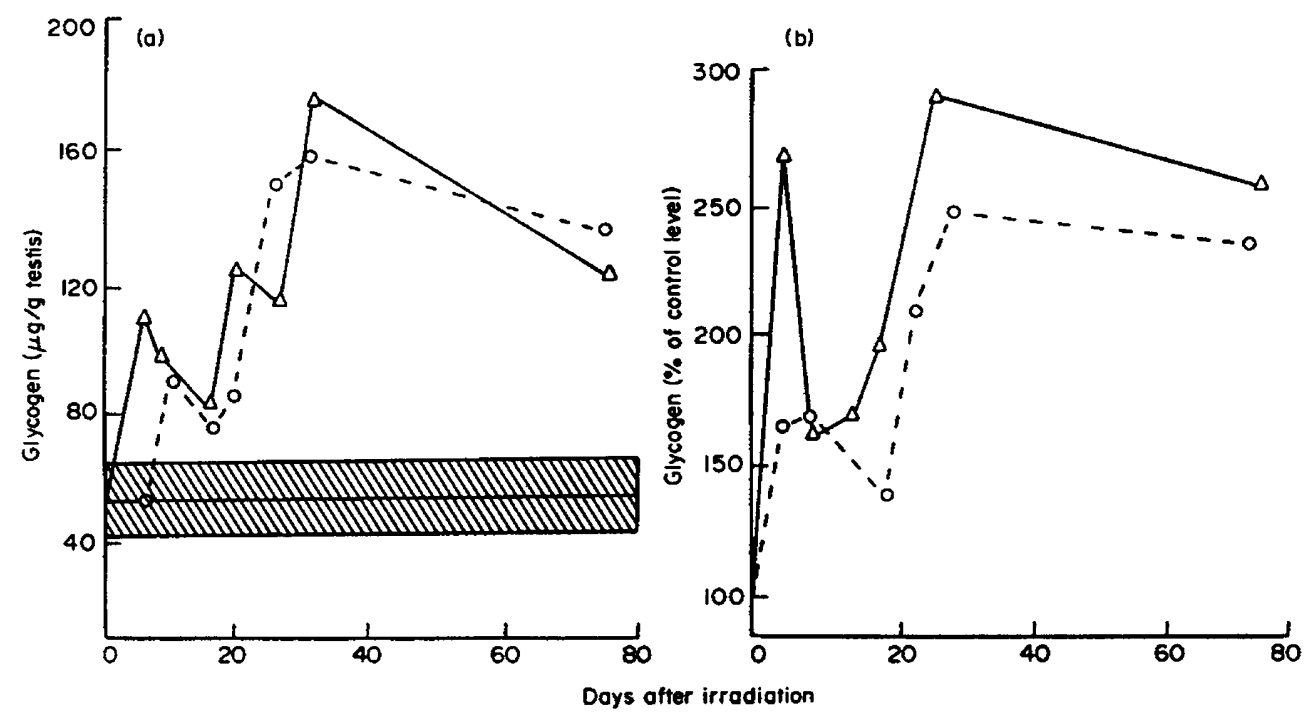

TEXT-FIG. 1. Effect of partial body $\gamma$-irradiation of rats on testicular glycogen expressed as (a) values/g testis, and (b) $\%$ of control levels $/ g$ testis. Horizontal lines and shaded area represent mean control levels \pm S.D. $O, 720 R$ dose; $\triangle, 2000 R$ dose.

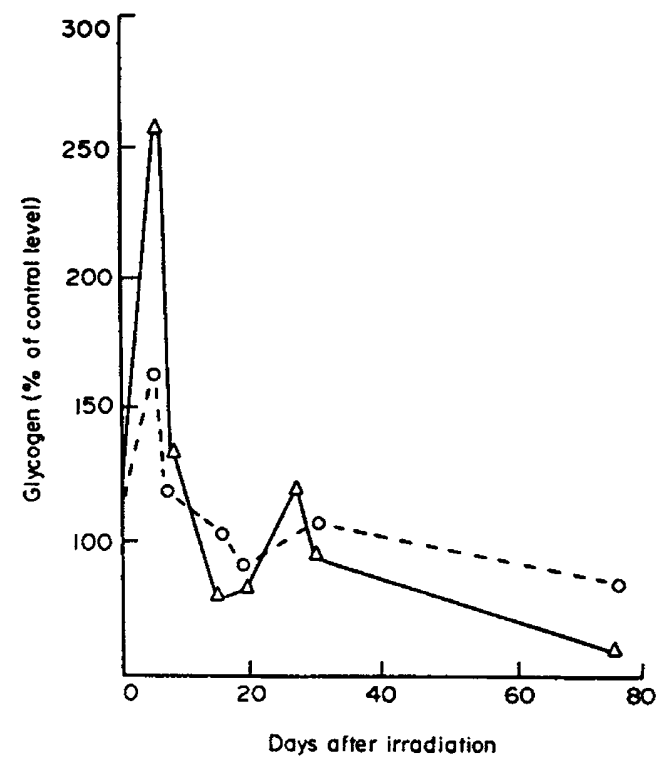

TEXT-FIG. 2. Effect of lapse of time after irradiation on the glycogen level per rat testis. $O, 720 \mathrm{R}$ dose; $\triangle, 2000 \mathrm{R}$ dose.

is not clear. Reduced glycolysis due to inhibition of phosphorylase, an enhanced rate of glycogen synthetase reaction, an increased rate of glyconeogenesis, shrinkage of the testicular tubules and the direct effect of radiation on glycolysis and citric acid cycle components may be some of the factors responsible for the higher content of glycogen in irradiated testes. The increased glycogen 


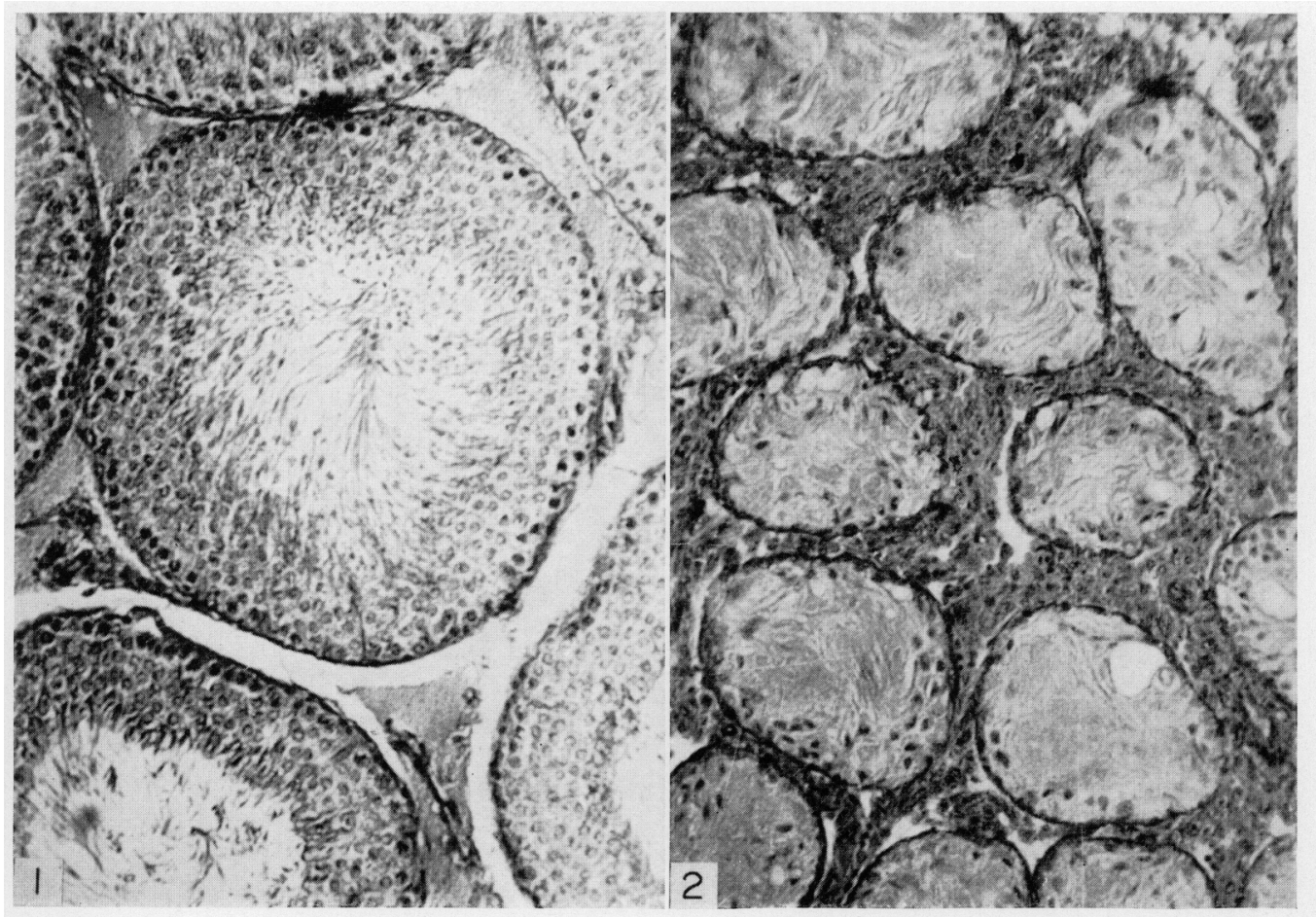

Sections from rat testis after fixing in Bouin's fluid and staining with haematoxylin and eosin.

FrG. 1. Control testis. The tubules are filled with mature and immature germinal cells. $\times 100$.

Frg. 2. Testis 26 days after partial body irradiation at $2000 \mathrm{R}$. The germinal cells have disappeared from the seminiferious tubules and the interstitium shows hyperplasia. $\times 100$. 


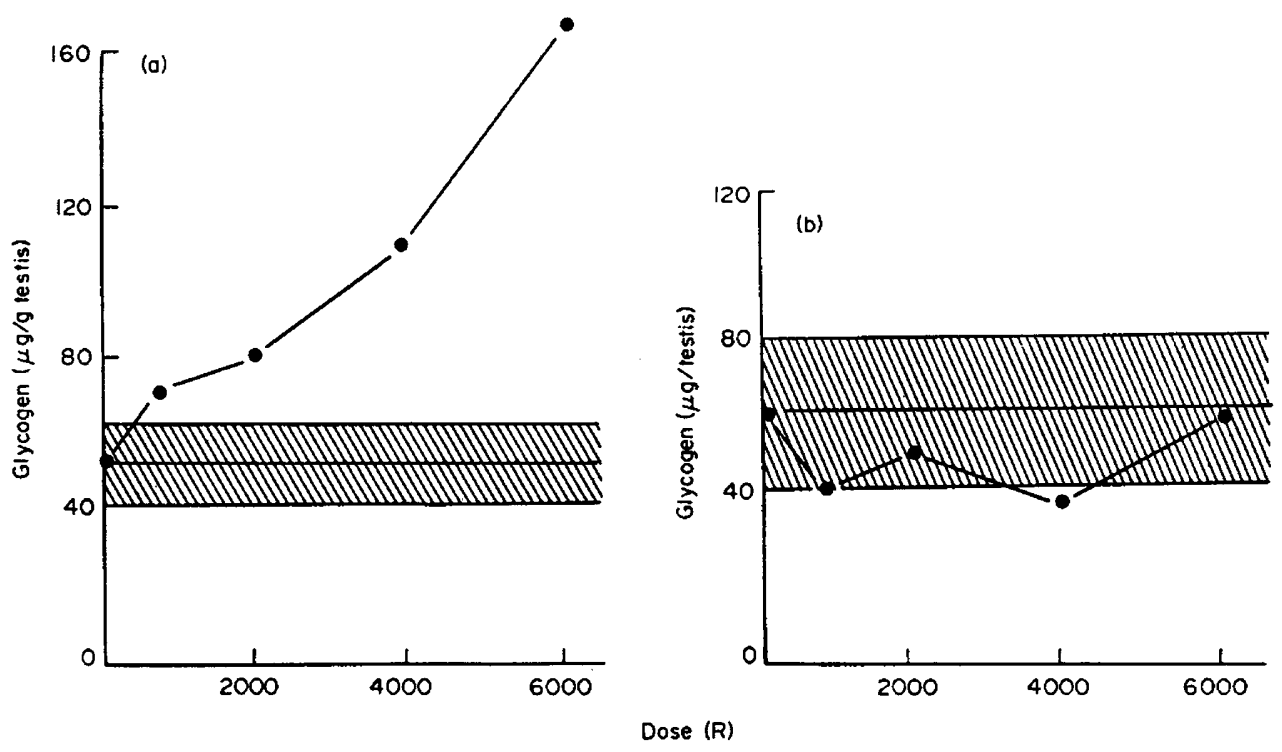

TEXT-FIc. 3. Effect of different doses of radiation on the glycogen of rat testes 15 days after irradiation. (a) Values/g testis. (b) Values/testis. The horizontal lines and shaded areas represent mean control levels \pm S.D.

levels/g and /testis by Day 5 seem to suggest a real rise in the glycogen content of the germinal cells still remaining in the testis in various stages of degeneration. Total phosphorylase in the presence of adenosine 5' phosphate and glucose-6phosphatase declines in the irradiated testis (Gupta \& Bawa, 1971). The deficiency of glucose-6-phosphatase may be associated in some way with glycogenesis (Gupta \& Bawa, 1971). From Day 5 to Day 20, the germinal cells are presumably declining in number, which would account for the fall in glycogen/testis. The concentration then increases at a time when only Sertoli cells are left (Pl. 1, Figs 1 and 2). The amount of glycogen/testis, however, becomes steady in the normal range.

Table 1. Testis weight following partial body $\gamma$-irradiation of rats

\begin{tabular}{c|c|c|c}
\hline \multirow{2}{*}{$\begin{array}{c}\text { Dose } \\
(R)\end{array}$} & $\begin{array}{c}\text { Days after } \\
\text { irradiation }\end{array}$ & \multicolumn{2}{|c}{ Weight of testis $(\mathrm{g})$} \\
\cline { 2 - 4 } & & Control & Irradiated \\
\hline 720 & 5 & 1.21 & $1 \cdot 17$ \\
& 8 & 1.17 & 0.84 \\
& 17 & 1.12 & 0.60 \\
& 24 & 1.18 & 0.56 \\
& 29 & 1.18 & 0.58 \\
& 74 & 1.28 & 0.46 \\
& 5 & $1 \cdot 11$ & $0 \cdot 79$ \\
& 8 & 1.19 & 0.85 \\
& 15 & 1.37 & 0.68 \\
& 19 & 1.32 & 0.66 \\
& 29 & 1.21 & $0 \cdot 42$ \\
& 74 & 1.22 & 0.29 \\
\hline
\end{tabular}


This suggests that, following irradiation, there is an initial real increase related to degeneration of the germinal epithelium and that once the germinal cells have been lost, the normal pattern emerges. In the absence of germinal cells (Pl. 1, Fig. 2) after irradiation, it seems possible that much of the glycogen actually resides in the non-germinal cells, (possibly the Sertoli cells) although the normal rat testis contains glycogen in such low concentrations that it is difficult to detect it by histochemical methods (Nicander, 1957; Leiderman \& Mancini, 1969). Glycogen may be acting as a reserve substrate for enhanced endogenous respiration by the irradiated testis (Steinberger \& Wagner, 1961) and is associated with hyperplasia of the interstitial tissue (Gupta \& Bawa, 1972, 1975, and Pl. 1, Fig. 2) through hyperactivity of phosphate-shunt enzymes (Gupta \& Bawa, 1972). The accumulation of glycogen has been reported by Harkonen \& Kormano (1971) in cryptorchid testis and the pattern appears to be similar to that in irradiated testis.

The authors wish to thank Dr P. N. Chhuttani and Dr B. D. Gupta of Postgraduate Institute of Medical Education and Research, Chandigarh, for providing irradiation facilities.

\section{REFERENCES}

Eluis, L. G. (1970) Radiation effects. In The Testis, Vol. III, p. 333. Eds. A. D. Johnson, W. R. Gomes and N. L. VanDemark. Academic Press, New York.

FREE, M. J. (1970) Carbohydrate metabolism in testes. In The Testis, Vol. II, p. 125. Eds. A. D. Johnson, W. R. Gomes and N. L. VanDemark. Academic Press, New York.

Gupta, G. S. \& Bawa, S. R. (1971) Phosphatases in testes and epididymides of albino rats after partial body $\gamma$-irradiation. 7. Reprod. Fert. 27, 451.

Gupta, G. S. \& BAwA, S. R. (1972) Radiation induced hyperplasia and oxidative enzymes in rat testes. Proc. 4th Int. Congr. Biophysics, Moscow.

Gupta, G. S. \& BAwA, S. R. (1975) Radiation effects on testes. II. Incorporation of ${ }^{65} \mathrm{Zn}$ after localized gamma irradiation of rats. F. Reprod. Fert. (in press).

Harkonen, M. \& Kormano, M. (1971) Energy metabolism of the normal and cryptorchid rat testis. 7. Reprod. Fert. 25, 29.

Leiderman, N. \& Mancini, R. E. (1969) Glycogen content in rat testis from postnatal to adult ages. Endocrinology, 85, 607.

Nicander, L. (1957) A histochemical study on glycogen in testes of domestic and laboratory animals with special reference to variations during spermatogenic cycle. Acta neerl. morphol. 1, 233.

Seifter, S., Dayton, S., Movic, B. \& Muntwyler, E. (1960) The estimation of glycogen with the anthrone reagent. Archs Biochem. 25, 191.

Steinberger, E. \& WAGNER, G. (1961) Observations on endogenous respiration of rat testicular tissue. Endocrinology, 69, 305. 